\title{
Science, Technology, Engineering, and Mathematics (STEM) Learning on Student's Science Process Skills and Science Attitudes
}

\author{
Sri Setiawaty, Nuraini Fatmi, Ayu Rahmi, Ratna Unaida, Fakhrah, \\ Izkar Hadiya, Iryana Muhammad, Mursalin, Muliana, Rohantizani \\ and Alchali1 \\ Faculty of Education, Malikussaleh University, Aceh, Indonesia \\ Ratih Permana Sari \\ Faculty of Education, Universitas Samudra Langsa, Aceh, Indonesia
}

\begin{abstract}
Purpose - The aim of this study is to determine the effects of inquiry instruction incorporating with STEM learning on Chemistry Education of Malikussaleh University students' science process skills and science attitudes.

Design/Methodology/Approach - The pre-experimental design, which is a mixed method approach is used in the study that included a pretest-posttest one group model and descriptive quantitative.

Findings - As a result of data analysis that STEM learning significantly enhances students' science process skills and attitudes toward inquiry instruction. This study examines how participation in a semester long inquiry-based STEM learning project that involves interdisciplinary skills, sociological research on attitudes, and behaviors enhances the scientific and quantitative literacies of STEM students.

Research Limitations/Implications - Quantitative research is needed to determine the more common effects of learning outcomes. However, this study only determines a self-assessment on science attitudes. The other one is a limitation on the participants and reviewing aspects of learning with more variables in order to obtain more optimal results.

Practical Implications - The results of this study have practical implications in terms of hands-on activities. The learning model can be used to explain the concept of multidisciplinary studies and particularly to students and their parents. It will be a useful model for lecturers, personal tutors, and any other practitioners involved in hands-on activities.

Originality/Value - This paper innovative at a conceptual level of education development for students, graduates, and it is very simple descriptive papers. It will be of value to anybody with an interest in education competitiveness issues.
\end{abstract}

Keywords STEM, science process skill, science attitude, inquiry

(C) Sri Setiawaty, Nuraini Fatmi, Ayu Rahmi, Ratna Unaida, Fakhrah, Izkar Hadiya, Iryana Muhammad, Mursalin, Muliana, Rohantizani, Alchalil, Ratih Permana Sari. Published in the Emerald Reach Proceedings Series. Published by Emerald Publishing Limited. This article is published under the Creative Commons Attribution (CC BY 4.0) licence. Anyone may reproduce, distribute, translate and create derivative works of this article (for both commercial and non-commercial purposes), subject to full attribution to the original publication and authors. The full terms of this licence may be seen at http://creativecommons.org/licences/by/4.0/legalcode

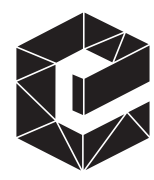

Emerald Reach Proceedings Series Vol. 1 pp. $575-581$ Emerald Publishing Limited 2516-2853 DOI 10.1108/978-1-78756-793-1-00036 
All papers within this proceedings volume have been peer reviewed by the scientific committee of the Malikussaleh International Conference on Multidisciplinary Studies (MICoMS 2017).

\section{Introduction}

Science is knowledge initially acquire and develop based on experiments but further developments are also derived and develop science-based theory. Science also related to the natural way of finding out about a systematic manner, so that science is not just the acquisition of knowledge but also a process of discovery. As explained in the curriculum 2013, science was developed as integrative science subjects rather than as educational disciplines, namely as applicative-oriented education, the development of thinking and creative skills, study skills, curiosity, and the development of caring and responsible attitude towards the social and natural environment.

In this era of curriculum, considerable attention is being focused on curriculum integration. The inquiry is an aspect of transformational teaching and learning on curriculum integration and involves activity and skills which has been spurred by the development of several learning principles and methods of instruction.

For this aims of this study was to determine the effects of hands-on activities and skills incorporating inquiry-based STEM learning and teaching on Malikussaleh University chemistry education student's science process skills and attitudes toward science lessons. It compared the performance of the students using hands-on activities incorporating inquirybased STEM learning and teaching to students using a traditional science curriculum. From a science perspective, inquiry-based STEM learning and teaching engage in the investigative nature of science. The basic process skills in this study were determined as observing, classifying, planning of experiment, defining operationally with using tools and materials in the experiment, measuring, recording and interpreting to applicated of learning concept. Then, performance in social studies have improved by a self-assessment on science attitudes with materials preparation of multimedia power point.

Integrative STEM education is very effective way to engage students in higher-order critical thinking and problem solving skills by placing rigorous mathematics and science in the context of technology and engineering (Central Pennsylvania Workforce Development Corporation, 2010) and STEM educated student is a problem solver, logical thinker, technologically literate, and able to relate his own culture to the learning (Morrison, 2006).Learning the pure science become less interesting, the dead knowledge or text bookish and finally it brought to low in learning motivation. Environment science is a topic both in chemistry and biology subject but they are taught in segregated views and not a integrated elaboration as supposed to be in the STEM.

All this time, some of the methods used by lectures are expository, verification and makes students become very passive. Students learn calculus or biochemistry in college but none knows the application. Students learn calor transfer in physics but they do not know how refrigerator works. Students learn distillation in analytical chemistry but they do not separate water with oils. According to (Moomaw and Davis, 2010), that desires effect of developing individuals'lifelong learning skills, as well as the potential for sustained interest in STEM topics and issues, and should be exposed to positive and authentic STEM learning experiences and throughout their educational pathways in the STEM education.

\section{Methods}

Research design

A mixed method approach was used in this study that included a pretest-posttest one group model and pre-experimental design. This method is used to determine science process skills 
improvement and self-assessment on science attitudes of basic chemistry concepts between the students who received learning method inquiry-based STEM learning and students who receive conventional learning.

\section{Participants}

This study held in academic year 2016/2017 in Malikussaleh University of chemistry education. The sample in this study is third semester students, as a selected sample based on purposive sampling technique (Sugiyono, 2004). This study involves the independent variable is inquiry-based STEM learning and dependent variable are science process skills and science attitudes.

\section{Collecting of data}

The data were collected through testing. Both instruments have been through the validation process. The data were collected using a pretest and posttest for students' science process skills, presentation group observation sheets, and student activities, as well as lecture and student questionnaires.

\section{Analysis of data}

Data processed through several stages, including the validity, reliability, test difficulty levels, and different power on the instrument to be used in research. Furthermore, to determine the increase in science attitudes and science process skills is calculating N-Gain from the pretest and posttest students. Later, the data were tested for normality test analysis (Lilifors test) is the prerequisite of data distribution, homogeneity of variance test (Barlett test), and test the equality of two mean correlations between the dependent variable of Pearson/Kendal dan Spearman in SPSS 18 for windows to data analysis.

\section{Results}

\section{Learning activities with STEM}

Activities of students for learning with inquiry-based STEM derived from the observation sheet that has been provided and observations. The results of the implementation of learning by observation method based STEM prepared based learning steps. Based on the observation, learning activities that have been done already reflects the process of inquirybased STEM learning. Average activities of students at every learning stage performing well, it is based on data enthusiasm of students is $3.41 \%$. This suggests that learning with practical methods facilitate lecture inquiry-based STEM teaching for basic chemistry as well as provide opportunities for students to construct knowledge so that learning objectives be achieved with better and more effective than conventional learning. This is in line with the research (Andriani et al., 2011), who found that the application of guided inquiry learning model can improve the enthusiastic students in the implementation of learning activities and students become the focus in the implementation of learning. In his research, a feasibility study was obtained for $88.7 \%$ and $73.3 \%$ the percentage of student activity. Furthermore, explained that STEM education in high schools have been intensively studying and reported to give great impact on promoting integrated science in school following the development of science and technology as well as improving student learning motivation and creativity (Goonatilake, and Bachnak, 2012; Zhe et al., 2010)

\section{STEM \\ Learning on \\ Student's \\ Science}




\section{Proceedings of Improvement of students' science process skills}

MICoMS 2017 Increased N-Gain data of students' science process skills obtained from normalized gain. Based on analysis data of class describe that average score comparisons N-Gain of experiments class $0.58 \%$ higher than the $0.41 \%$ control class that included in the medium category. The Comparison diagram average scores of pretest, posttest, and N-GainScience Process Skills are shown in Figure 1.

578

Then, Improving students' mastery of each science process skills indicator can be described from the diagram in Figure 2. N-Gain mastery of each science process skills indicator between the experimental class students was higher than the control class, except for using tools and materials indicator that have an equal on N-Gain value. To this end, students in the control class can use and handle tools safely and accurately measure.

Increased highest N-Gain for the experimental class is on observation and classification indicator is equal to 0.71 (Figure 2). Based on N-Gain scores on each indicator, it can be concluded that in an inquiry-based STEM activities, students can discover knowledge through the exploration of objects in the daily lives of students compared to the verification

Figure 1.

Comparison diagram average scores
Figure 2.

N-Gain diagram of each science process skills indicator
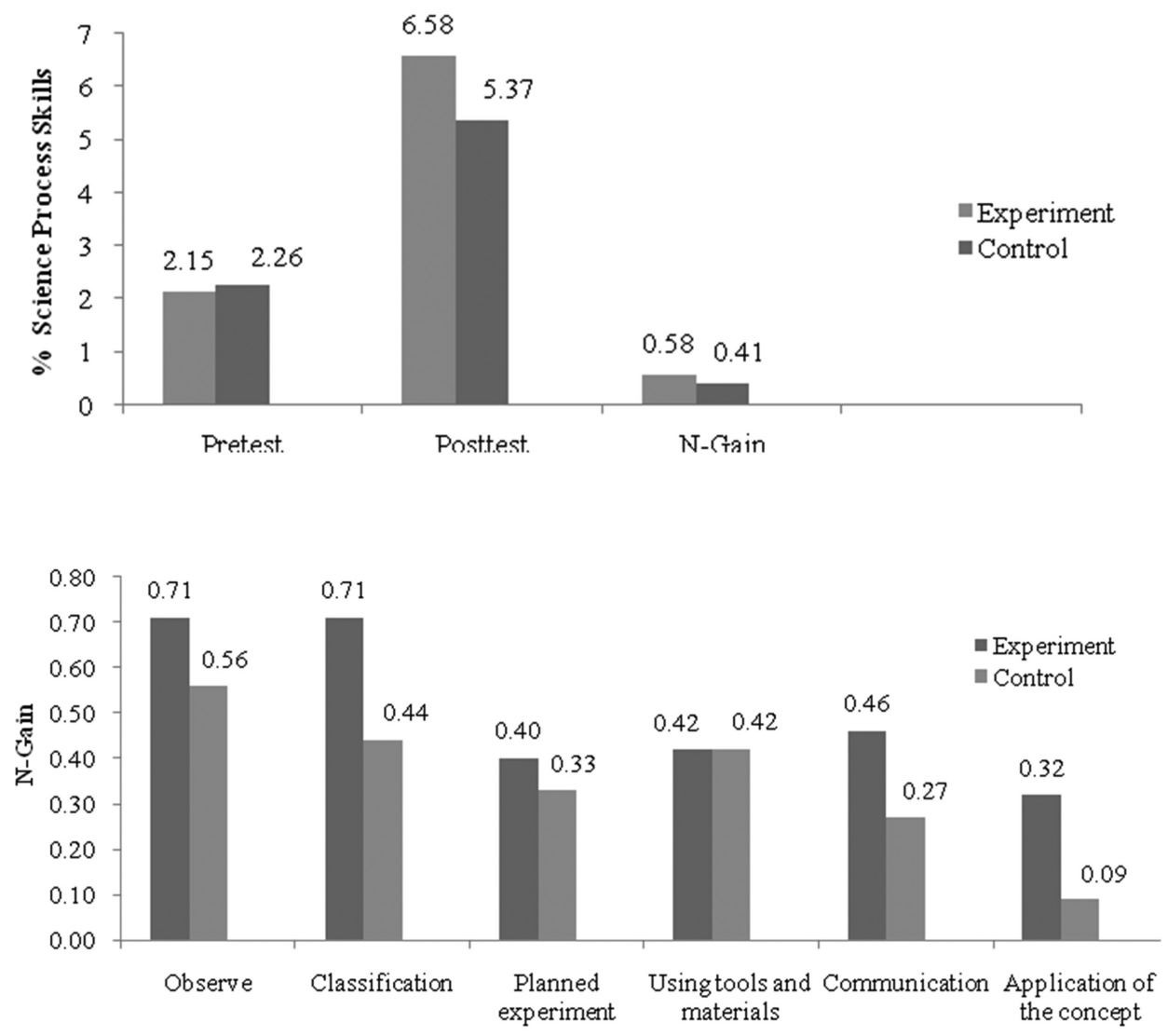

Science process skills indicator 
lab activities. According to (Haryono, 2006), through a learning process that integrates a series of science process skills in the learning process, allowing students to gain experience and relatively diverse learning more meaningful. In relation to that, (Wilke and Straits, 2005) explained, scientific inquiry exercises typically serve as the primary source of science process skills development and inquiry is used to teach science process skills.

In the analysis, prerequisite of science process skills test have distribution of pretest is not normal and have the same level of variance (homogeneous). Meanwhile, posttest of control class is normally distributed and the experimental class distribution is abnormal. However, both classes have a level of learning that is not the same variance (inhomogeneous). This means that most of the data are not eligible $\operatorname{sig}>\alpha=0.05$. So that the mean test performed with non parametric test (Mann-Whitney test), where as the N-Gain used for parametric test ( $\mathrm{t}$ test) because the data were normally distributed and homogeneous.

Table 1 known that the inquirybased STEM learning can improve the science process skills. This is indicated from the data posttest and N-Gain, which has a significantly smaller extent than $\alpha=0.05(0.018<\alpha=0.05)$ in the data posttest and $0.003<\alpha=0.05$ for the data of N-Gain. This means that there are differences in the activity of the students before and after a given treatment in the experimental class with a method that is an inquiry-based STEM learning. This is consistent with the results of the study (Khan et al., 2011), that the performance of the experimental group was significantly better than the control group at the time of the posttest. The difference between the two mean statistically significant at the 0.05 level. The overall results of the study indicate that the guided inquiry can be used as a backup strategy to support traditional teaching methods.

\section{The effectiveness of self-assessment on science attitudes}

Implementation of self-assessment on science attitudesgiven to students that is preparation of presentation materials from a multimedia powerpoint of chemistry experimental. Students are given the time of at least a week before presentation.The analysis results to presentation materials showed that $70 \%$ on the definition description and chemistry experimental activities $75 \%$. For component parts of completeness of presentation as learning objectives already showed in accordance with the sub concepts which has been determined is $90 \%$, subconcepts discussion is $85 \%$, systematics of list writing a bibliography with a percentage of $90 \%$ and presentation of power point slides is $90 \%$. As obtained by the result of the study (McCright, 2012) shownthat participation in the inquiry-based learning project had a positive effect on

\begin{tabular}{|c|c|c|c|c|c|}
\hline \multirow[b]{2}{*}{ Data } & \multicolumn{2}{|c|}{ Mann-Whitney Test } & \multirow{2}{*}{$\begin{array}{l}\text { Independent } \\
\text { sample t test }\end{array}$} & \multirow[b]{2}{*}{ Conclusion } & \multirow[b]{2}{*}{ Table 1.} \\
\hline & $z$ value & $\overline{\text { Sign }}$ & & & \\
\hline Pretest & $-0,176$ & 0,860 & - & $\overline{\text { Not Different }}$ & A different test \\
\hline Posttest & $-2,360$ & 0,018 & - & Different & average of science \\
\hline N-Gain & - & 0,003 & 3,11 & Different & process skills \\
\hline
\end{tabular}

Table 2.

The result of

\begin{tabular}{|c|c|c|c|c|}
\hline Variable & rcount. & $r$ table pearson & Conclusion & formative \\
\hline SPS-Self assesment & $0.362^{* *}$ & 0.301 & Significant & process skills \\
\hline
\end{tabular}


Proceedings of experimental group students' perception of how scientific sociology is and their favorable MICoMS 2017 attitudes and improved students' attitudes toward sociology specifically and social science in general.

The effectiveness of implememtation in formative assessment to science process skillsone of them seen from the number of contributions in self-assessment to form science attitudes and students' science process skills. To know the number of contributions selfassessment on science attitudes to students' science process skills conducted correlation test with correlated students' observation rubric and science process skills posttest. The result of correlation test self-assessment on science attitudes to science process skills for experiment class are shown in Table 2.

The correlation test of formative assessment is shown in Table 2. As obtained that $r$ count experiment class significant to science process skills with $r$ count $\geq r$ table value is 0.362 , where are both have $r$ countvalue greater than $r$ tableis 0.301 . This means there significantlyscience process skills between self-assessment on science attitudes.

\section{Conclusion}

The research results are shown in the application of STEM learning provide simultaneous influence of the students' science process skills and science attitudes on chemistry education. Furthermore, integrating STEM through project-based activities and skills has the potential of increasing the quality of learning. Students in the STEM need to develop interdisciplinary skills that help them understand the social dynamics of environmental problems and solutions. To that end, this study examines how participation in inquirybased learning project that involves sociological research on attitudes, and behavior enhances the scientific, motivation, and quantitative literacies of STEM students. Also, it is suggested that the lecturer can use this as an alternative learning by taking into account the characteristics of teaching for students to learn more active and able to construct their own knowledge based on inquiry learning stages, as well as similar studies need to be done by reviewing aspects of learning more wide with more variables in order to obtain more optimal results.

\section{References}

Andriani, N., Husaini, I. and Nurliyah, L., (2011), "Efektivitas Penerapan Pembelajaran Inkuiri terbimbing (Guided Inquiry) pada Mata Pelajaran Fisika Pokok Bahasan Cahaya di Kelas VIII SMP Negeri 2Muara Padang”. Prosiding Simposium Nasional Inovasi Pembelajaran dan Sains 2011, available at: http://www.prosiding.papsi.org.

Goonatilake, R. and Bachnak, R. A., (2012), "Promoting Engineering Education Among High School and Middle School Students". Journal of STEM Education, Vol. 13 No. 1, pp. 15-21.

Haryono. (2006),"Model Pembelajaran Berbasis Peningkatan Keterampilan Proses Sains”. Jurnal Pendidikan Dasar, Vol. 7 No. 1, pp. 1-13.

Khan, M. S., Hussain, S., Ali, R., Majoka, M. I. and Ramzan, M. (2011), "Effect of Inquiry Method on Achievement of Students in Chemistry at Secondary Level", International Journal of Academic Research, Vol. 3 No. 1, pp. 955-959.

McCright, Aaron, M. (2012), "Enhancing Students' Scientific and Quantitative Literacies Through an Inquiry-Based Learning Project on Climate Change", Journal of the Scholarship of Teaching and Learning, Vol. 12 No. 4, pp. 86-102. 
Moomaw, S. and Davis, J. A. (2010), "STEM Comes to Preschool", National Association for the Education of Young Children, Vol. 65 No. 5, pp. 12-14, 16-18.

Morrison, J. (2006), "Attributes of STEM Education: The Student, The School, The Classroom [Monograph]. Baltimore, MD: Teaching Institute for Excellence in STEM", available at: http:// www.tiesteach.org.

Sugiyono. (2004), "Metode Penelitian Pendidikan (Pendekatan Kuantitatif, Kualitatif, dan R\&D)". Alfabeta, Bandung.

Wilke, R.R. and Straits, W. J. (2005), "Practical Advice for Teaching Inquiry-based Science Process

STEM

Learning on

Student's

Science Skills in Biological Sciences", The American Biology Teacher, Vol. 67 No. 9, pp. 534-540.

Zhe, J., Doverspike, D., Zhao, J., Lam, P and Menzemer, C. (2010), "High School Bridge Program: A Multidisciplinary STEM Research Program', Journal of STEM Education, Vol. 11 No. 1, 2, pp. 61-67.

\section{Corresponding author}

Sri can be contacted at srisetiawaty.unimal@gmail.com 